\title{
Screening of Sesame Varieties, Cultivars, Germplasm Lines and Elite Lines against Alternaria sesami
}

\author{
D. V. Pawar*, A. P. Suryawanshi and V. A. Kadam \\ Department of Plant Pathology, Vasantrao Naik Marathwada Krushi Vidhyapeeth, \\ Parbhani-431 402, Maharashtra, India \\ *Corresponding author
}

Keywords

Sesame, Screening, Alternaria sesami, Varieties, Cultivars

Article Info

Accepted:

07 November 2019

Available Online:

10 December 2019

\section{A B S T R A C T}

Sesame, (Sesamum indicum L.), is one of the world's ancient important oilseed crop cultivated in more than 55 countries of the world belonging to the family Pedaliaceae and native of India. Sesame cultivars / varieties presently under cultivation do not posses proven field resistance or tolerance and majority of them are more or less prone to the leaf blight disease (A. sesami). Thus, the present study was under taken with an aim to identify the resistance sources in the cultivars for further exploitation in resistance breeding programme. None of the sesame entry was found immune or resistant or highly susceptible to the disease. However, the eight entries viz., MT-11-1-13, RT-369, JLS-606-7-2, DS-7, RT-370, TKG22(NC), DS-26 and DS-334 during Kharif 2014-15 and during Kharif 2016-17 fifteen entries DS-44, TKG-478, RT-379, MT-2014-57, DS-45, JLS-710, DS-46, AT-338, GT-10(NC), VS-10-99, MT-2014-12, AT-345, MT-2014-14, RT-378 and MT-35(ZC-1) were found tolerant to the disease and rest of the test entries showed susceptible to highly susceptible reactions.

\section{Introduction}

India is among the largest vegetable oil economies in the world and it is ranks first in area and production among the sesame growing countries (Ashri, 1998). Sesame is extensively cultivated in India, China, Myanmar, Sudan, Nigeria, Mexico, Philippines, Korea, Thailand, Srilanka,
Pakistan, Egypt, East Africa and to a smaller extent to Ethiopia, Uganda, Venezuela, Turkey, Kenya, Tanzania, Somalia, Nigeria, USA, and Australia (Balasubramanian and Palemiappan, 2000). The area, production and productivity of sesame has been reported to be 74.40 and 19.01 lakh hectares, 33.40 and 8.10 lakh tons and 518 and $426 \mathrm{~kg} / \mathrm{ha}$, respectively, in the World and India (Anonymous, 2015). 
Major sesame growing states in India are: Rajasthan, Utter Pradesh, Madhya Pradesh, Gujarat, Andhra Pradesh, Orissa, West Bengal, Karnataka, Maharashtra, Tamil Nadu, Bihar and Assam. However, crop is grown in all the states of country. The total area in Maharashtra under sesame was 0.52 lakh hectares, with production 0.08 metric tones and productivity of $300 \mathrm{~kg} / \mathrm{ha}$ (Anonymous, 2015). In Maharashtra, popularly grown sesame varieties/cultivars are: JLT-26 (Padma), Phule-til-1, JLT-7 (Tapi), AKT-64, AKT-101, PKV-NT-11, JLT-408, N-8, Gujrat til-3.

Among the major factors responsible for lower yields, diseases play an important role. Sesame is also affected by many biotic and abiotic stresses. Among the biotic agents, fungi cause major diseases, followed by bacteria, viruses and nematodes. Among these diseases, at present leaf spot / blight caused by Alternaria sesame (Kawamura) is widespread and have continued to be the major constraints in the production and productivity of sesame all over the country in general as well as in the state of Maharashtra particularly. The disease was first reported by Dey (1948) from Uttar Pradesh, which later spread in sesame growing region of the country (Dolle, 1981; Kolte, 1985; Narute and Utikar, 1994; Tripathi et al., 2005). The disease (A. sesami) has been reported to cause 20 to 40 per cent yield losses all over India (Kumar and Mishra, 1992; Prasad and Reddy, 1997).

The disease appears from seedling stage to harvesting of crop. The infection remain continues even after harvesting of crop due to dew deposition on stem and pod during early morning. The fungus is known to cause seed rot, pre and post- emergence death of seedlings and infect all the above ground parts resulting in considerable loss in yield both quantitatively and qualitatively. Cultivation of resistant varieties is the most effective, cheap and ecofriendly method of combat the disease, so screening of genotype was carried out at the research farm of AICRP (Safflower) VNMKV, Parbhani.

\section{Materials and Methods}

The field experiments were conducted at the research farm of AICRP (Safflower), Vasantrao Naik Marathwada Krishi Vidyapeeth, Parbhani during two Kharif seasons of 2014-15 and 2016-17, to assess the reactions of sesame varieties, cultivars, germplasm lines and elite lines, against $A$. sesami, under natural epiphytotics. A total of 13 and 30 entries during Kharif, 2014-15 and 2016-17 were sown at $30 \times 10 \mathrm{~cm}$ spacing. The test entries were replicated thrice during both the years. Observations on Alternaria blight disease intensity were recorded on five randomly selected plants, applying 0-9 grade disease rating scale (Mayee and Datar, 1986), as detailed in Table 1 at 15 days interval starting first observation at initiation of the disease and last at 15 days before harvest of the crop.

The data was averaged and per cent Alternaria blight disease intensity was worked out by applying following formula (McKinney, 1923).

Summation of numerical ratings observed

$$
\begin{aligned}
& \text { PDI = -------------------------X } 100 \\
& \text { No. of leaves / plants observed } \\
& \mathrm{x} \text { maximum grade }
\end{aligned}
$$

Based on average per cent disease intensity, the test sesame entries were categorized as follows.

\section{Statistical analysis}

The data recorded in the experiment was statistically analyzed (Panse and Sukhatme, 
1978) using VNMAU-STAT statistical programme, at Central Computer Laboratory, Vasantrao Naik Marathwada Krishi Vidyapeeth, Parbhani.

\section{Results and Discussion}

\section{Disease reactions of sesame entries}

Results (Table 2 and Plate 1) revealed that during Kharif, 2015-16, natural epiphytotics of A. sesami, all 13 test entries of sesame exhibited different reactions against $A$. sesami. However, eight entries viz., MT-11-1-13, RT369, JLS-606-7-2, DS-7 RT-370, TKG22(NC), DS-26 and DS-334 showed tolerant reaction with mean blight intensity in the range of 10.56 to 24.45 per cent; four entries viz., GT-10(NC), RT-371, ZONAL CHECK and LT-210 showed susceptible reaction with moderate mean blight intensity in the range of 26.67to 33.34 per cent and one entrieviz., TKG-501 exhibited moderately resistant reaction with mean blight intensity of 8.89 per cent. None of the sesame entry was found immune or resistant or highly susceptible to the disease. Results (Table 3 and Plate 2) revealed that during Kharif, 2016-17, under natural epiphytotics of $A$. sesami, all 30 test entries of sesame exhibited different reactions against $A$. sesami. However, fifteen entries viz DS-44, TKG-478, RT-379, MT-2014-57, DS45, JLS-710, DS-46, AT-338, GT-10(NC), VS-10-99, MT-2014-12, AT-345, MT-201414, RT-378 and MT-35(ZC-1) showed tolerant reaction with mean blight intensity in the range of 14.07 to 25.18 per cent; ten entries viz., RT-376, AT-312, SVT-222, AT-334, RT377, COS-13006, TKG-511, ZONAL CHECK, JTS-8(ZC-2) and NIRMAL(ZC-3) showed susceptible reaction with moderate mean blight intensity in the range of 26.67 to 42.22 per cent; three entries viz., TKG-15-02, TKG-15-06 and AT-314 exhibited highly susceptible reaction with higher mean blight intensity in the range of 51.11 to 59.27 per cent and two entries viz., JLT-709 andTKG22(NC), showed moderately resistant reaction with blight intensity in the range of 8.89 to 10.37 per cent. None of the sesame entry was found immune or resistant to the disease. These results are in conformity most of the entries / varieties with the findings of those reported earlier by several workers against, Alternaria sesami of sesame (Samuel et al., 1972; Dolle 1981; Marri et al., 2012) (Table 4).

Table.1 Alternaria blight disease rating scale

\begin{tabular}{|c|c|}
\hline Rating scale & Description \\
\hline 0 & No symptoms on the leaf. \\
\hline 1 & Small, irregular brown spots covering 1 per cent or less of the leaf area. \\
\hline 3 & $\begin{array}{l}\text { Small, round to irregular brown spots with concentric rings covering 1-10 } \\
\text { per cent of the leaf area. }\end{array}$ \\
\hline 5 & $\begin{array}{l}\text { Round to irregular brown lesions enlarging, with concentric rings } \\
\text { covering } 11-25 \text { per cent of the leaf area. }\end{array}$ \\
\hline 7 & $\begin{array}{l}\text { Lesions enlarging and coalescing to form irregular brown patches with } \\
\text { concentric rings and covering } 26-50 \text { per cent of the leaf area. Lesions } \\
\text { also appeared on stem petioles and pods. }\end{array}$ \\
\hline 9 & $\begin{array}{l}\text { Lesions enlarged coalesced to forming irregular, dark brown patches with } \\
\text { concentric rings covering } 51 \text { per cent or more of the leaf area. Lesions on } \\
\text { stem petioles and pods. }\end{array}$ \\
\hline
\end{tabular}


Plate.1 Screening of sesame cultivars, germplasm lines against Alternaria blight disease during Kharif, 2014-15
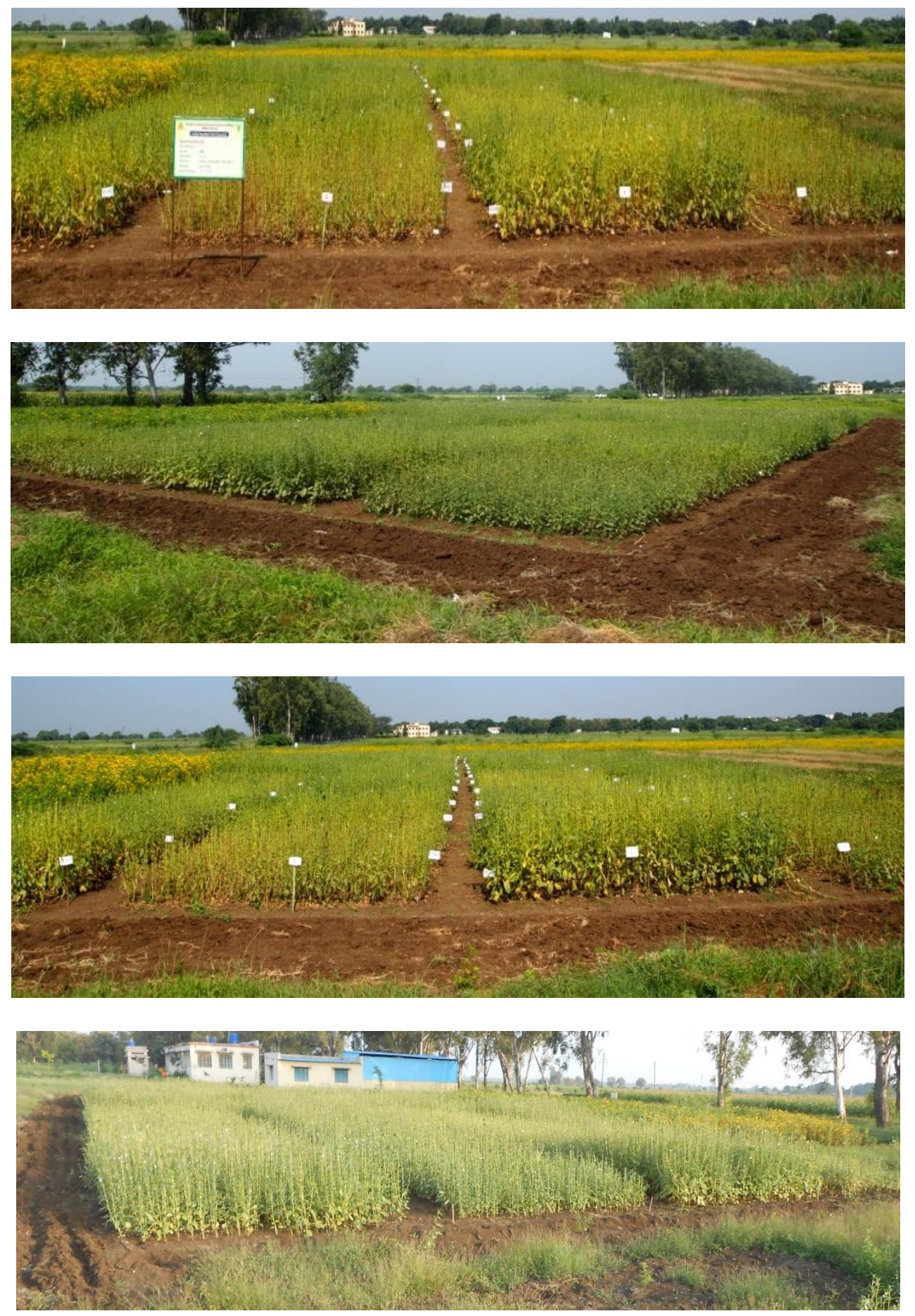
Plate.2 Screening of sesame cultivars, germplasm lines against Alternaria blight disease during Kharif, 2016-17
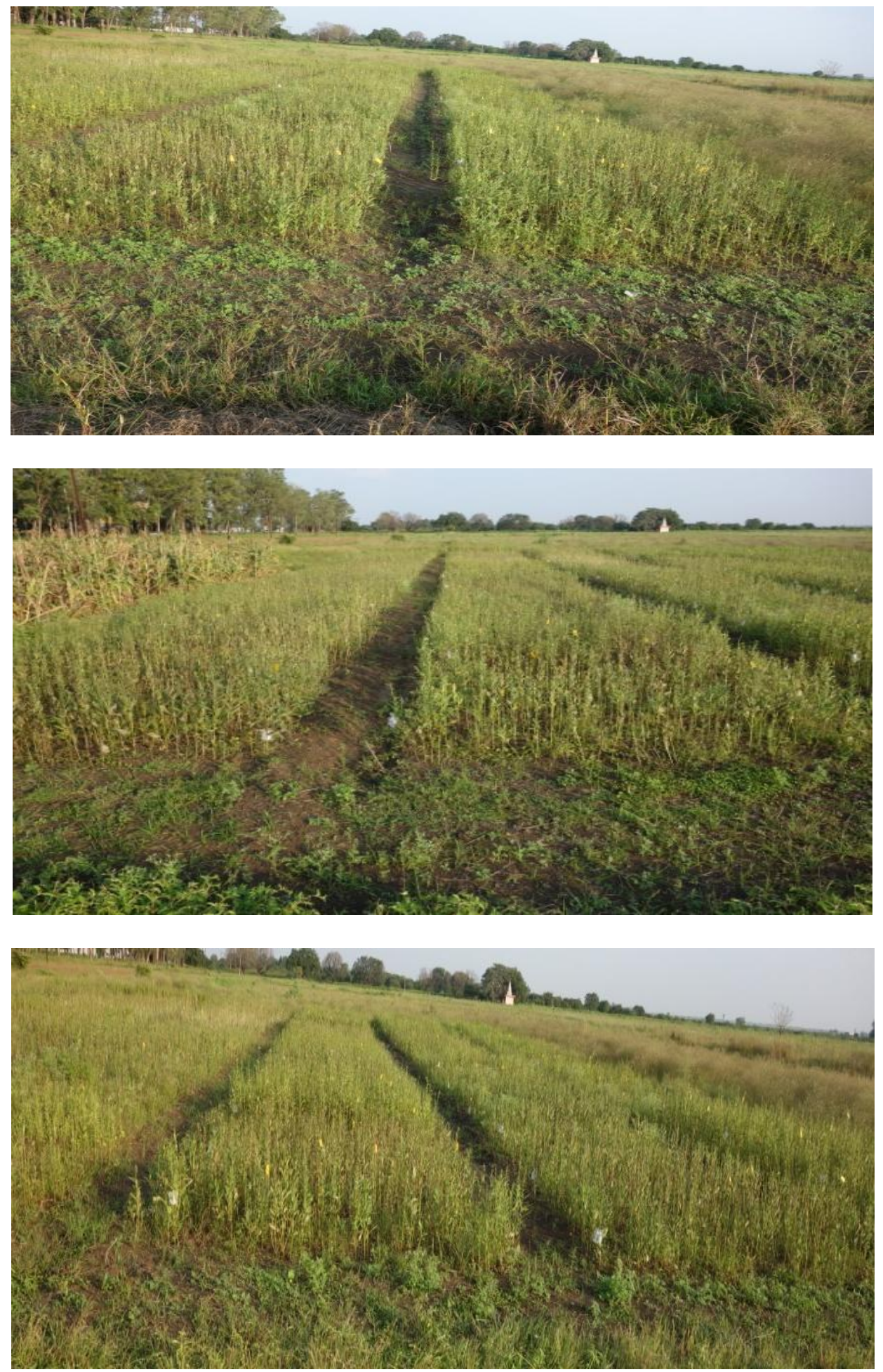
Table.2

\begin{tabular}{|c|c|c|}
\hline Disease Rating & Area affected (\%) & Disease reactions \\
\hline $\mathbf{0}$ & No disease & Immune (I) \\
\hline $\mathbf{1}$ & $<1$ & Resistant (R) \\
\hline $\mathbf{3}$ & 01 to 10 & Moderately resistant (MR) \\
\hline $\mathbf{5}$ & 11 to 25 & Tolerant (T) \\
\hline $\mathbf{7}$ & 26 to 50 & Susceptible (S) \\
\hline $\mathbf{9}$ & 51 and above & Highly susceptible (HS) \\
\hline
\end{tabular}

Table.3 Reactions of sesame cultivars, germplasm lines against Alternaria blight disease during Kharif, 2014-15

\begin{tabular}{|c|c|c|c|}
\hline Sr. No. & Entries & Av. PDI (\%) & Reactions \\
\hline $\mathbf{1}$ & MT-11-1-13 & 24.45 & $\mathrm{~T}$ \\
\hline $\mathbf{2}$ & RT-369 & 19.45 & $\mathrm{~T}$ \\
\hline $\mathbf{3}$ & JLS-606-7-2 & 21.67 & $\mathrm{~T}$ \\
\hline $\mathbf{4}$ & IVT-14-4 & 33.34 & $\mathrm{~S}$ \\
\hline $\mathbf{5}$ & DS-7 & 13.34 & $\mathrm{~T}$ \\
\hline $\mathbf{6}$ & RT-370 & 11.11 & $\mathrm{~T}$ \\
\hline $\mathbf{7}$ & TKG-22(NC) & 18.33 & $\mathrm{~T}$ \\
\hline $\mathbf{8}$ & DS-26 & 17.22 & $\mathrm{~T}$ \\
\hline $\mathbf{9}$ & TKG-501 & 8.89 & $\mathrm{MR}$ \\
\hline $\mathbf{1 0}$ & RT-371 & 29.44 & $\mathrm{~S}$ \\
\hline $\mathbf{1 1}$ & ZONAL CHECK & 26.67 & $\mathrm{~S}$ \\
\hline $\mathbf{1 2}$ & LT-210 & 28.89 & $\mathrm{~T}$ \\
\hline $\mathbf{1 3}$ & DS-334 & 10.56 & $\mathbf{1 . 4 3}$ \\
\hline & $\mathbf{S E} \pm$ & & $\mathbf{4 . 1 2}$ \\
\hline & CD $\mathbf{P}=\mathbf{0 . 0 5})$ & & $\mathbf{1 0 . 9 1}$ \\
\hline
\end{tabular}

Table.4 Reactions of sesame cultivars, germplasm lines against Alternaria blight disease during Kharif, 2016-17

\begin{tabular}{|c|c|c|c|}
\hline Sr. No. & Entries & Av. PDI (\%) & Reactions \\
\hline $\mathbf{1}$ & TKG-15-02 & 51.11 & HS \\
\hline $\mathbf{2}$ & DS-44 & 21.48 & T \\
\hline $\mathbf{3}$ & JLT-709 & 10.37 & MR \\
\hline $\mathbf{4}$ & TKG-478 & 17.78 & T \\
\hline $\mathbf{5}$ & TKG-22(NC) & 8.89 & MR \\
\hline $\mathbf{6}$ & RT-379 & 17.04 & T \\
\hline $\mathbf{7}$ & MT-2014-57 & 19.26 & T \\
\hline $\mathbf{8}$ & DS-45 & 24.44 & T \\
\hline $\mathbf{9}$ & RT-376 & 42.22 & S \\
\hline $\mathbf{1 0}$ & JLS-710 & 15.56 & T \\
\hline $\mathbf{1 1}$ & AT-312 & 30.37 & S \\
\hline $\mathbf{1 2}$ & DS-46 & 21.48 & T \\
\hline $\mathbf{1 3}$ & SVT-222 & 31.11 & S \\
\hline
\end{tabular}




\begin{tabular}{|c|c|c|c|}
\hline $\mathbf{1 4}$ & AT-338 & 16.30 & T \\
\hline $\mathbf{1 5}$ & TKG-15-06 & 53.33 & HS \\
\hline $\mathbf{1 6}$ & AT-334 & 28.89 & S \\
\hline $\mathbf{1 7}$ & GT-10(NC) & 20.00 & T \\
\hline $\mathbf{1 8}$ & VS-10-99 & 18.52 & T \\
\hline $\mathbf{1 9}$ & MT-2014-12 & 15.56 & T \\
\hline $\mathbf{2 0}$ & RT-377 & 36.30 & S \\
\hline $\mathbf{2 1}$ & AT-345 & 22.22 & T \\
\hline $\mathbf{2 2}$ & MT-2014-14 & 12.59 & T \\
\hline $\mathbf{2 3}$ & COS-13006 & 26.67 & S \\
\hline $\mathbf{2 4}$ & RT-378 & 14.07 & T \\
\hline $\mathbf{2 5}$ & TKG-511 & 36.30 & S \\
\hline $\mathbf{2 6}$ & AT-314 & 59.27 & HS \\
\hline $\mathbf{2 7}$ & ZONAL & 28.89 & S \\
\hline & CHECK & & \\
\hline $\mathbf{2 8}$ & MT-35(ZC-1) & 25.18 & T \\
\hline $\mathbf{2 9}$ & JTS-8(ZC-2) & 33.33 & S \\
\hline $\mathbf{3 0}$ & NIRMAL(ZC-3) & 26.67 & S \\
\hline-- & SE \pm & -- & $\mathbf{1 . 9 4}$ \\
\hline-- & CD $(\mathbf{P}=\mathbf{0 . 0 5})$ & -- & $\mathbf{5 . 5 0}$ \\
\hline-- & CV & -- & $\mathbf{1 2 . 8 3}$ \\
\hline
\end{tabular}

\section{References}

Anonymous (2015).Ministry of Agri. Gove. India. (ON 410).

Ashri, A. (1998). Sesame breeding. Plant Breed Reviews. 16: 179-228.

Balasubramanian, T. N. and S. P. Palemiappan. (2000). Sesame In: P.S. Rathore (ed.) Techniques and Management of Field crop Production. Agrobios (India), Jodhpur. Pp. 178196.

Dey, P.K. (1948). Plant Pathology Administrative Report of Agriculture Department, Uttar Pradesh, India. : 4346.

Dolle, U. V. 1981 Epidemiology and control of leaf blight of sesame caused by $A$. sesami (Kawamura). Mahanty and Behera. Plant Pathology News Letter 2: 1-10.

Kolte, S. J. (1985). Disease of Annual Edible Oilseed Crops. (Vol.-II): Rapeseed,
Mustard, Safflower and Sesame diseases. CRC Press Inc, Boca Raton, Florida, USA. Pp. 135.

Kumar, P. and Mishra U. S. (1992) Diseases of Sesamum indicum in Rohilkhand: intensity and yield loss. Indian Phytopath. 45 (1): 121-122.

Marri, N.A., Lodhi, A.M., Shah, G.S. and Maitlo, S.A. (2012) Response of different sesame cultivars to Alternaria leaf spot disease (Alternaria sesami) Pak. J. Phytopathol. 24(2): 129-132.

Mayee, C. D. and Datar, V. V. (1986). Phytopathomethory: Technical Bulletin Published by Marathwada Agric. Univ., Parbhani (M.S.) India. Pp. 100-104.

McKinney (1923).A new system of grading plant diseases. J. Agric. Res. 26 : 195218.

Narute, T. K., and Utikar, (1994). Efficacy and economics of fungicidal control of 
Alternaria leaf blight of sesamum. J. Maha. Agric. Sci. 19. Pp. 449.

Panse, V. G. and Sukhatme, P. V. (1978). Statistical methods for agricultural workers (3rd ed.). ICAR, New Delhi Pub. Pp. 157-165.

Prasad, P. R. and Reddy, S. R. (1997). Diseases of two districts (Warangal and Karimnagar) of Andhara Pardesh. Microbio. Biotech. PP. 169-174.
Samuel, S. G. Govindaswamy C. V. and Vidhyasekaran P. (1972). Studies on Alternaria blight disease of gingelly. The Madras Agricultural Journal. Pp. 882-886.

Tripathi, U. K., Mehata, N and Sangwan M. S. (2005). Fungal and bacterial diseases of sesame. In: Diseases of oilseed crops (eds.) Indus Pub. New Delhi, India. Pp. 269-303.

\section{How to cite this article:}

Pawar, D. V., A. P. Suryawanshi and Kadam, V. A. 2019. Screening of Sesame Varieties, Cultivars, Germplasm Lines and Elite Lines against Alternaria sesami. Int.J.Curr.Microbiol.App.Sci. 8(12): 534-541. doi: https://doi.org/10.20546/ijcmas.2019.812.071 